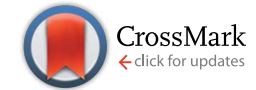

Cite this: RSC Adv., 2017, 7, 6735
Received 11th November 2016 Accepted 29th December 2016

DOI: $10.1039 / c 6 r a 26638 j$

www.rsc.org/advances

\section{Study on the efficient PV/TE characteristics of the self-assembled thin films based on bismuth telluride/cadmium telluride}

\author{
Vivekanandan Raman, ${ }^{a}$ Dinah Punnoose, ${ }^{a}$ Pari Baraneedharan, ${ }^{b}$ \\ Sunkara Srinivasa Rao, ${ }^{a}$ Chandu V. V. M. Gopi, ${ }^{a}$ Venkatesh S, ${ }^{C}$ S Brahadeeswaran ${ }^{d}$ \\ and Hee-Je Kim*a
}

Solar radiation has a spectral distribution ranging from short wavelengths (200-800 nm, visible part) to long wavelengths (800-3000 nm, heat part). Cadmium telluride and bismuth telluride are well known photovoltaic (PV) and thermoelectric (TE) materials, respectively. CdTe converts light energy into electricity and $\mathrm{Bi}_{2} \mathrm{Te}_{3}$ converts heat into electricity. To effectively use the entire solar spectrum for energy conversion, a new type of solar cell based on a $\mathrm{Bi}_{2} \mathrm{Te}_{3} / \mathrm{CdTe}$ composite in a core/shell structure was designed and prepared using a wet chemical method. X-ray diffraction and high-resolution transmission electron microscopy confirmed the formation of $\mathrm{Bi}_{2} \mathrm{Te}_{3} / \mathrm{CdTe}$ in a core/shell structure with high crystallinity. $\mathrm{Bi}_{2} \mathrm{Te}_{3}$ nanoparticles function as built-in nanoscale electron generators to convert heat into electricity and CdTe functions as a photovoltaic cell. The efficiency of the thin film solar cell device was found to be $2.5 \%$ at room temperature and $4.8 \%$ when exposed to sunlight. The combined PV and TE modules resulted in an overall power conversion efficiency of $4.8 \%$.

\section{Introduction}

Solar energy is the cleanest and the most abundant renewable energy source available. $\mathrm{CdTe}, \mathrm{CuIn}(\mathrm{Ga}) \mathrm{Se}_{2}$, and c-Si are advanced materials that are used as absorber materials in solar cells. ${ }^{1}$ Although these materials have high efficiency, the lack of abundance, high toxicity levels, and high production costs are problems that have prompted researchers to search for new materials and/or newer and easier synthesis routes. Therefore, continuous efforts are being made to find new, cost-effective photovoltaic materials with good conversion efficiency. Solar radiation has a spectral distribution from the short wavelength range, 200-800 $\mathrm{nm}$ (light part), to the long wavelength range, 800-3000 nm (heat part). Better control of light scattering and electronic transport through a semiconductor is crucial for improving the solar efficiency. Photovoltaic cells (PV), such as CdTe, can only convert the short wavelengths of solar energy into electricity and the remaining long wavelength solar radiation is waste heat. Thermoelectric materials (TE), such as $\mathrm{Bi}_{2} \mathrm{Te}_{3}$, convert the waste heat into electricity. $\mathrm{Bi}_{2} \mathrm{Te}_{3}$ has a high

\footnotetext{
${ }^{a}$ Department of Electrical and Computer Engineering, 2, Busandaehak-ro 63 beon-gil, Geumjeong-gu, Busan 46241, Korea. E-mail: heeje@pusan.ac.kr

${ }^{b}$ Alternative Energy and Nanotechnology Laboratory, Indian Institute of Technology Madras, Chennai, 600036, India

${ }^{c}$ Department of Physics, Indian Institute of Science, Bangalore, India

${ }^{d}$ Department of Physics, Anna University BIT Campus, Tiruchirappalli, Tamilnadu, India
}

Seebeck coefficient and can generate electricity, even at room temperature. ${ }^{2}$ Considerable efforts have been made to combine both PV and TE technologies to maximally utilize the entire solar spectrum. These hybrid technologies that combine the modules of PV and TE cannot solve the problems of solar energy synergy utilization at the material level because the functions of PV and TE modules are independent of each other. On the other hand, it will be beneficial if both the PV and TE functions can be achieved in a single material. If this single material can be prepared in a nanostructure, it will be more efficient. Nanoparticles of CdTe have good photoluminescence properties and have been used in the production of solar cells. CdTe nanoparticles are prepared via aqueous and non-aqueous synthesis routes. Compared to non-aqueous synthesis, aqueous synthesis is more reproducible, cheaper, and less toxic. In addition, the prepared samples are more water-soluble and bio-compatible. ${ }^{3}$ To prepare nanorods, a seed-mediated growth technique was performed, in which the precursor was added dropwise and the capping agent assisted in the growth of nanorods. ${ }^{4,5}$ This study reports the integration of photovoltaic CdTe and thermoelectric $\mathrm{Bi}_{2} \mathrm{Te}_{3}$ materials into a single photoelectrode in the form of a core/shell nanostructure. Interestingly, this material showed a conversion efficiency of $4.8 \%$ when exposed to sunlight.

Core/shell nanorods have been produced by a layer-by-layer self-assembly method. This is an effective technique for the construction of well-defined nanostructures. Hengguo Wang et al. reported that the LBL technique is facile and relatively controllable and they confirmed the incorporation of $\mathrm{Fe}_{3} \mathrm{O}_{4}$ and 
quantum dots (QDs) into a single structure. The shell produced by this method is meant to be a functional hybrid nanoshell. ${ }^{6-9}$ The alternating adsorption of oppositely charged materials gives rise to a layer-by-layer (LBL) self-assembly deposition method, through which hydrogen-bonding interactions and electrostatic forces hold the nanostructures assembly together. ${ }^{10-12}$ The aim of developing $\mathrm{Bi}_{2} \mathrm{Te}_{3} / \mathrm{CdTe}$ core shell nanorods is to harvest electricity from both thermal energy and light energy produced by the sun. Jie Yang et al. proposed that self-assembled $\mathrm{Bi}_{2} \mathrm{Te}_{3} / \mathrm{CdTe}$ nanosheets showed an increase in the thermoelectric performance of $\mathrm{Bi}_{2} \mathrm{Te}_{3}$ due to the addition of CdTe, thus reaching a Seebeck coefficient of $-182.2 \mu \mathrm{V} \mathrm{K}^{-1}$ at $300 \mathrm{~K}$, which is slightly higher than that of the bulk $\mathrm{Bi}_{2} \mathrm{Te}_{3}$ sample, $-180.0 \mu \mathrm{V} \mathrm{K} \mathrm{K}^{-1}$. This clearly shows that CdTe will also enhance the thermoelectric performance of $\mathrm{Bi}_{2} \mathrm{Te}_{3}$. Solar cells based on nanoparticles have higher solar efficiency because of their large surface area. ${ }^{13}$ Therefore, the increase in the surface area of planar nanorod carpets has been proposed to enhance solar light harvesting. ${ }^{\mathbf{1 4 - 1 6}}$

\section{Experimental section}

\subsection{Materials}

All chemicals, such as bismuth(III) nitrate pentahydrate $\left(\mathrm{Bi}\left(\mathrm{NO}_{3}\right)_{3} \cdot 5 \mathrm{H}_{2} \mathrm{O}\right)$, tellurium powder $(\mathrm{Te})$, potassium hydroxide $(\mathrm{KOH})$, polyvinyl alcohol (PVA), cadmium sulphate $\left(\mathrm{CdSO}_{4}\right)$, and sodium borohydride $\left(\mathrm{NaBH}_{4}\right)$, were purchased from Aldrich and used without further purification.

\subsection{Synthesis of $\mathrm{Bi}_{2} \mathrm{Te}_{3} / \mathrm{CdTe}$ core shell thin film nanostructures}

The front conductor influences the conductivity and plays a large role in the performance of a solar cell. An increase in the carrier mobility in the conductive FTO transparent conducting oxide layer provides lower absorptivity and lower resistivity. ${ }^{17} \mathrm{~A}$ FTO is properly cleaned to avoid weak adhesion, whereas a coating of CdS is deposited on the surface of the FTO. Acid exposure of the FTO will compromise the uniform deposition of CdS and affect the performance of the solar cell. ${ }^{18} \mathrm{CdS}$ has high band width $(2.4 \mathrm{eV})$ and acts as a windows layer for the cells, which plays a vital role in observing sunlight. In a clean FTO glass substrate, a three layer coating was deposited. The FTO substrate was masked and a 50-100 nm CdS layer was coated by thermal vapor deposition and annealed at $250{ }^{\circ} \mathrm{C}$ for 10 minutes. The CdS coating thickness affects the performance of the solar cell. The CdS should be thick enough because interdiffusion is promoted by the $\mathrm{CdCl}_{2}$ washing at the end of the deposition. The interdiffusion usually takes place without $\mathrm{CdCl}_{2}$. It has negative effects on cell operation. When the interdiffusion is strong enough, the light current is decreased. It has been claimed that a narrow interdiffusion of less than $100 \mathrm{~nm}$ between CdS and CdTe allows the smoother transition between both lattices, which should relax the surface states. When the thickness increases, the photo current decreases and absorption occurs. ${ }^{19}$ During the deposition of $\mathrm{Bi}_{2} \mathrm{Te}_{3} / \mathrm{CdTe}$, interdiffusion between CdTe and CdS occurred. Moreover, CdS should be thick enough to not to be fully consumed by CdTe. ${ }^{20}$ $\mathrm{Bi}_{2} \mathrm{Te}_{3} / \mathrm{CdTe}$ core/shell nanorods were prepared by a wet chemical method. Bismuth(III) nitrate pentahydrate $(0.04 \mathrm{~mol})$ was placed in $10 \mathrm{~mL}$ of double-distilled water (DDW). Tellurium (0.06 mol) in $10 \mathrm{~mL}$ of DDW was mixed with bismuth nitrate solution and stirred. Subsequently, $0.5 \mathrm{~mol}$ of $\mathrm{KOH}$ was added to the abovementioned solution after $5 \mathrm{~min}$. The CdS-coated FTO substrate was then immersed in the prepared solution. About $0.04 \mathrm{~mol}$ of the reducing agent, $\mathrm{NaBH}_{4}$, was added dropwise to reduce the bismuth nitrate and tellurium to bismuth telluride nanoparticles. ${ }^{21}$ The reducing agent is oxidized because it loses electrons in the redox reaction. The first step involves the reduction of $\mathrm{Bi}\left(\mathrm{NO}_{3}\right)_{3} \cdot 5 \mathrm{H}_{2} \mathrm{O}$ and tellurium. When $\mathrm{H}_{2} \mathrm{O}$ is added to $\mathrm{Bi}\left(\mathrm{NO}_{3}\right)_{3} \cdot 5 \mathrm{H}_{2} \mathrm{O}$, salt separates into $\mathrm{Bi}^{3+}$ and $6 \mathrm{NO}^{-}$ions, whereas in the case of Te powder, Te changes into $\mathrm{Te}^{2-}$. When $\mathrm{NaBH}_{4}$ is added, these ions form clusters. In the second stage, the clusters coalesce to produce small particles with radius of $20-50 \mathrm{~nm}$. This is followed by a metastable state, where the particles maintain the constant size for around 5-10 $\mathrm{min}$. After 10-20 $\mathrm{min}$, the last coalescence phase takes place to generate final $\mathrm{Bi}_{2} \mathrm{Te}_{3}$ nanoparticles about the size of 150-250 nm.

$$
\begin{gathered}
\mathrm{Bi}\left(\mathrm{NO}_{3}\right)_{3} \cdot 5 \mathrm{H}_{2} \mathrm{O} \underset{\mathrm{H}_{2} \mathrm{O}}{\longrightarrow} \mathrm{Bi}^{3+}+6 \mathrm{NO}^{-} \\
\mathrm{Te} \underset{\mathrm{NaBH}_{4}}{\longrightarrow} \mathrm{Te}^{2-}
\end{gathered}
$$

$$
3 \mathrm{Te}^{2-}+2 \mathrm{Bi}^{3+} \rightarrow \mathrm{Bi}_{2} \mathrm{Te}_{3}
$$

When $\mathrm{NaBH}_{4}$ is added followed by stirring, nanorods of $\mathrm{Bi}_{2} \mathrm{Te}_{3}$ are formed via a self-assembly mechanism. Herein, in the self-assembly mechanism, at the critical concentration, the molecules start to interact with each other resulting in the nucleation of crystals. Using hydrogen bonding and electrostatic or ionic forces, $\mathrm{Bi}_{2} \mathrm{Te}_{3}$ clusters with itself to form nanorods. When PVA is added, it bonds to $\mathrm{Bi}_{2} \mathrm{Te}_{3}$. PVA plays a critical role in bonding $\mathrm{Bi}_{2} \mathrm{Te}_{3}$ and CdTe. PVA attracts the CdTe nanoclusters due to hydrogen bonding and forms core/shell nanorods, as shown in Fig. 1. A $0.1 \mathrm{~g}$ sample of polyvinyl alcohol (PVA) was added to the $\mathrm{Bi}_{2} \mathrm{Te}_{3}$ solution under stirring to form bonds with the $\mathrm{Bi}_{2} \mathrm{Te}_{3}$ nanoparticles. After $30 \mathrm{~min}$ of heating at $70{ }^{\circ} \mathrm{C}$, the polymer PVA transformed the $\mathrm{Bi}_{2} \mathrm{Te}_{3}$ nanoparticles into nanorods, and the solution turned black and coated the CdS substrate. Cadmium sulfate and tellurium were then mixed in $20 \mathrm{~mL}$ of DDW with 0.04 and 0.06 molarity, respectively, and stirred well for $20 \mathrm{~min}$. The solution was then poured into the $\mathrm{Bi}_{2} \mathrm{Te}_{3}$ nanorods solution, where CdTe forms a shell over $\mathrm{Bi}_{2} \mathrm{Te}_{3}$. The polymer plays a crucial role in reducing CdTe to nanoparticles and attaching over $\mathrm{Bi}_{2} \mathrm{Te}_{3}$. This mixture was kept at $70{ }^{\circ} \mathrm{C}$ and stirred well for $30 \mathrm{~min}$. CdTe was coated over $\mathrm{Bi}_{2} \mathrm{Te}_{3}$ and the substrate was washed with $\mathrm{CdCl}_{2}$ and distilled water, and then dried and annealed at $400{ }^{\circ} \mathrm{C}$ for $4 \mathrm{~h}$. This procedure was followed to prepare different concentrations of bismuth telluride with 


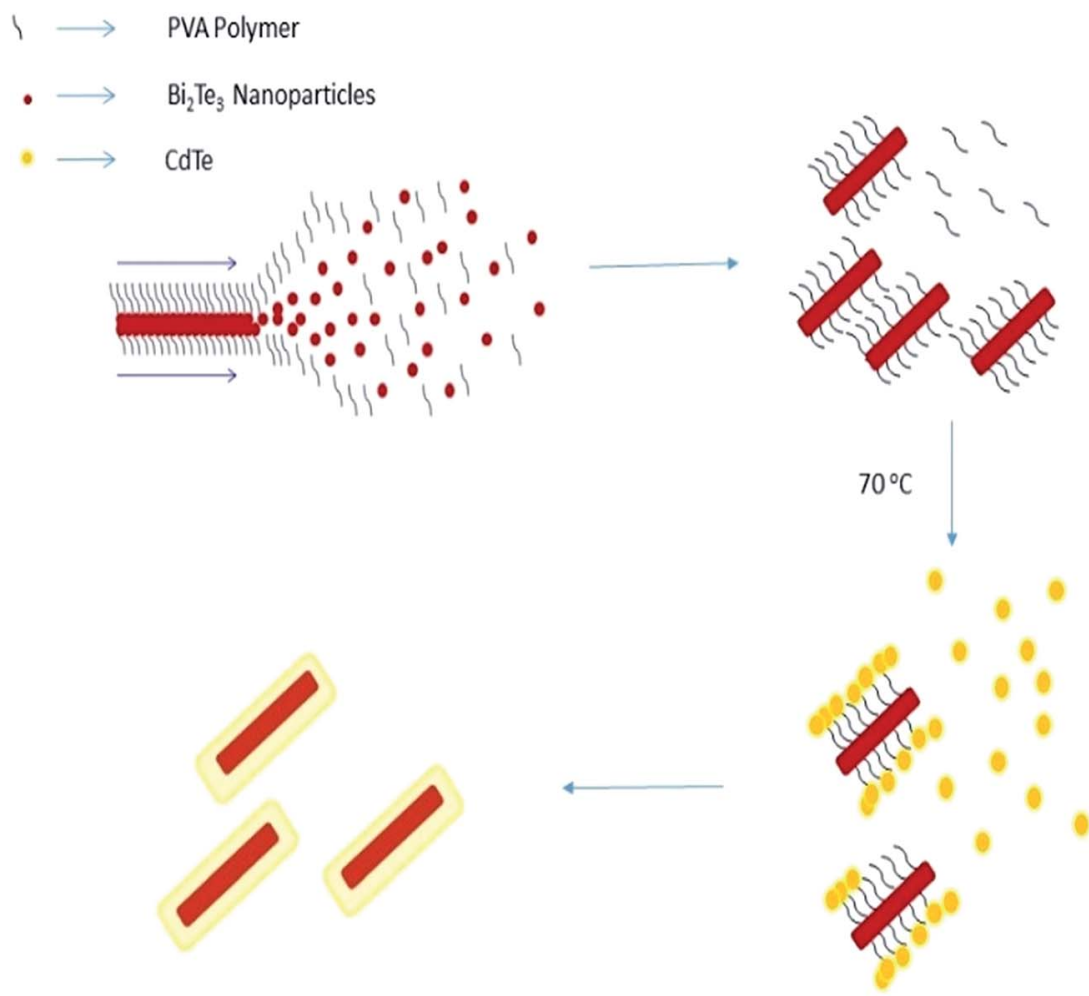

Fig. 1 Self-assembly of $\mathrm{Bi}_{2} \mathrm{Te}_{3} / \mathrm{CdTe}$ with the help of a PVA polymer.

cadmium telluride at ratios of $1: 3,1: 1$, and $3: 1$. Annealing at high temperatures encourages CdS/CdTe interdiffusion during growth, larger grain size, and generally provides a higher $V_{\mathrm{oc}}{ }^{22}$ This $\mathrm{Bi}_{2} \mathrm{Te}_{3} / \mathrm{CdTe}$ will act as a p-type semiconducting layer, whereas CdS will act as an n-type semiconducting layer. Therefore, these two layers form a $\mathrm{p}-\mathrm{n}$ junction. The back contact was coated with gold to reduce the resistance and increase the performance. A Cu wire was separately attached to the FTO and gold contact to complete the circuit. ${ }^{20}$

\subsection{Characterization}

The phase identification of $\left(\mathrm{Bi}_{2} \mathrm{Te}_{3}\right)_{75}(\mathrm{CdTe})_{25},\left(\mathrm{Bi}_{2} \mathrm{Te}_{3}\right)_{50}(\mathrm{CdTe})_{50}$, and $\left(\mathrm{Bi}_{2} \mathrm{Te}_{3}\right)_{25}(\mathrm{CdTe})_{75}$ was investigated using X-ray diffraction (XRD; Bruker D8-Advance) with a $\mathrm{Cu}-\mathrm{K}_{\alpha}$ radiation $(\lambda=1.540 \AA$ ) source operated at $40 \mathrm{kV}$ and $30 \mathrm{~mA}$ in the range of $10-60^{\circ}$. The morphology of the sample was examined using high resolution transmission electron microscopy (HRTEM; Jem 2011, Jeol cop.) with a CCD $4 \mathrm{k} \times 4 \mathrm{k}$ camera (Ultra Scan $400 \mathrm{SP}$, Gatan cop.) at the Busan KBSI. X. The constituents and morphological changes of $\left(\mathrm{Bi}_{2} \mathrm{Te}_{3}\right)_{75}(\mathrm{CdTe})_{25},\left(\mathrm{Bi}_{2} \mathrm{Te}_{3}\right)_{50}(\mathrm{CdTe})_{50}$, and $\left(\mathrm{Bi}_{2} \mathrm{Te}_{3}\right)_{25}(\mathrm{CdTe})_{75}$ and the elemental compositions of the samples were examined using a field emission scanning electron microscope (FE-SEM, SU-70, Hitachi) operated at $10.0 \mathrm{kV}$ with an energy-dispersive X-ray spectroscopy (EDX) operated at $15 \mathrm{kV}$. The diffuse reflection of absorption spectra of $\left(\mathrm{Bi}_{2} \mathrm{Te}_{3}\right)_{75}(\mathrm{CdTe})_{25},\left(\mathrm{Bi}_{2} \mathrm{Te}_{3}\right)_{50}(\mathrm{CdTe})_{50}$, and $\left(\mathrm{Bi}_{2} \mathrm{Te}_{3}\right)_{25}(\mathrm{CdTe})_{75}$ was obtained using an Optizen $3220 \mathrm{UV}$ spectrophotometer. The photocurrent density-voltage characteristics of the thin film solar cell were obtained under one-sun

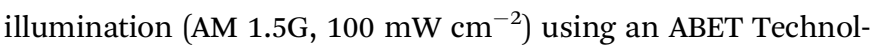
ogies (USA) solar simulator with an irradiance constancy of $\pm 3 \%$.

\section{Results and discussions}

$\mathrm{X}$-ray diffraction (XRD) revealed that the observed peaks corresponded to rhombohedral $\mathrm{Bi}_{2} \mathrm{Te}_{3}$ (JCPDS, 73-2036) and the XRD

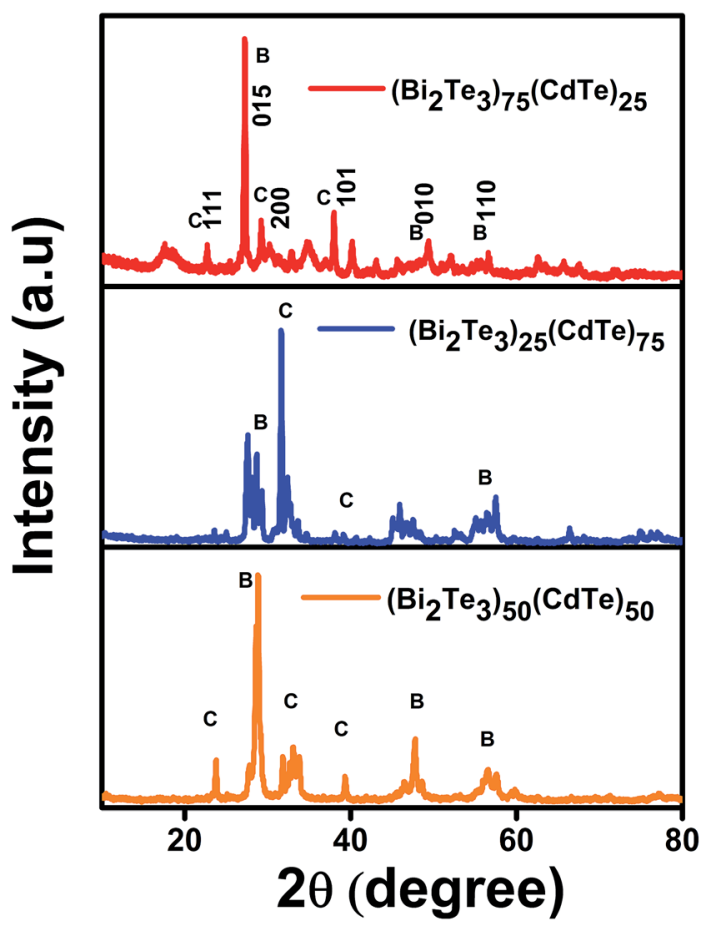

Fig. 2 XRD patterns of $\mathrm{Bi}_{2} \mathrm{Te}_{3} / \mathrm{CdTe}$ powder composites. XRD data for comparison of bismuth telluride percentage in cadmium telluride. 
pattern matched that of the JCPDS-89-3011 for the cubic CdTe in planes 200 and $111,{ }^{23}$ with a composition ratio of $\left(\mathrm{Bi}_{2}\right.$ $\left.\mathrm{Te}_{3}\right)_{25}(\mathrm{CdTe})_{75},\left(\mathrm{Bi}_{2} \mathrm{Te}_{3}\right)_{75}(\mathrm{CdTe})_{25}$, and $\left(\mathrm{Bi}_{2} \mathrm{Te}_{3}\right)_{50}(\mathrm{CdTe})_{50}$. The crystalline nature of $\mathrm{Bi}_{2} \mathrm{Te}_{3}$ and CdTe indicates the broadening of the XRD peaks in the form of nanoparticles. ${ }^{24}$ The XRD peaks suggest that the size of the $\mathrm{Bi}_{2} \mathrm{Te}_{3} / \mathrm{CdTe}$ particle material is small ranging from 200 to $250 \mathrm{~nm}$, which was observed from the broad peaks. ${ }^{25}$ Interestingly, Fig. 2 shows that for $\left(\mathrm{Bi}_{2} \mathrm{Te}_{3}\right)_{75}$ $(\mathrm{CdTe})_{25}$, the XRD peaks corresponding to $\mathrm{Bi}_{2} \mathrm{Te}_{3}$ are more intense than those corresponding to $\mathrm{CdTe}$, whereas for $\left(\mathrm{Bi}_{2}\right.$ $\left.\mathrm{Te}_{3}\right)_{25}(\mathrm{CdTe})_{75}$, the peaks corresponding to CdTe are dominant. The XRD pattern of $\left(\mathrm{Bi}_{2} \mathrm{Te}_{3}\right)_{50}(\mathrm{CdTe})_{50}$ closely matches that of $\left(\mathrm{Bi}_{2} \mathrm{Te}_{3}\right)_{75}(\mathrm{CdTe})_{25}$. This suggests that the crystalline phase ratio between $\mathrm{Bi}_{2} \mathrm{Te}_{3}$ and CdTe can be controlled by optimizing the ratio between $\mathrm{Bi}_{2} \mathrm{Te}_{3}$ and $\mathrm{CdTe}$.
Transmission electron microscopy (TEM) of annealed $\mathrm{Bi}_{2} \mathrm{Te}_{3} /$ CdTe revealed the formation of nanorods with sizes in the range of 100-250 nm (Fig. 3(a)). Fig. 3(b) clearly shows the core shell nanostructure of $\left(\mathrm{Bi}_{2} \mathrm{Te}_{3}\right)_{25}(\mathrm{CdTe})_{75}$. The selected area electron diffraction (SAED) pattern in Fig. 3(c) and (d) revealed the crystalline structural complexity and the fringes of CdTe with a lattice spacing of $0.35 \mathrm{~nm}$ corresponding to the (111) cubic planes of CdTe crystals (as shown in Fig. 3(c)), ${ }^{26,27}$ and $\mathrm{Bi}_{2} \mathrm{Te}_{3}$ has a lattice spacing of $0.13 \mathrm{~nm}$ corresponding to (125) trigonal planes. $\left(\mathrm{Bi}_{2}{ }^{-}\right.$ $\left.\mathrm{Te}_{3}\right)_{25}(\mathrm{CdTe})_{75}$ clearly shows nanorod formation (Fig. 4(a) and (b)), whereas formation of nanorods does not occur in samples $\left(\mathrm{Bi}_{2} \mathrm{Te}_{3}\right)_{75}(\mathrm{CdTe})_{25}$ and $\left(\mathrm{Bi}_{2} \mathrm{Te}_{3}\right)_{50}(\mathrm{CdTe})_{50}$. In Fig. 5, the field emission scanning electron microscopy (FESEM) also reveals a morphology of $\left(\mathrm{Bi}_{2} \mathrm{Te}_{3}\right)_{25}(\mathrm{CdTe})_{75}$ exhibiting nanorod formation. The colloidal morphology was observed in the TEM and the

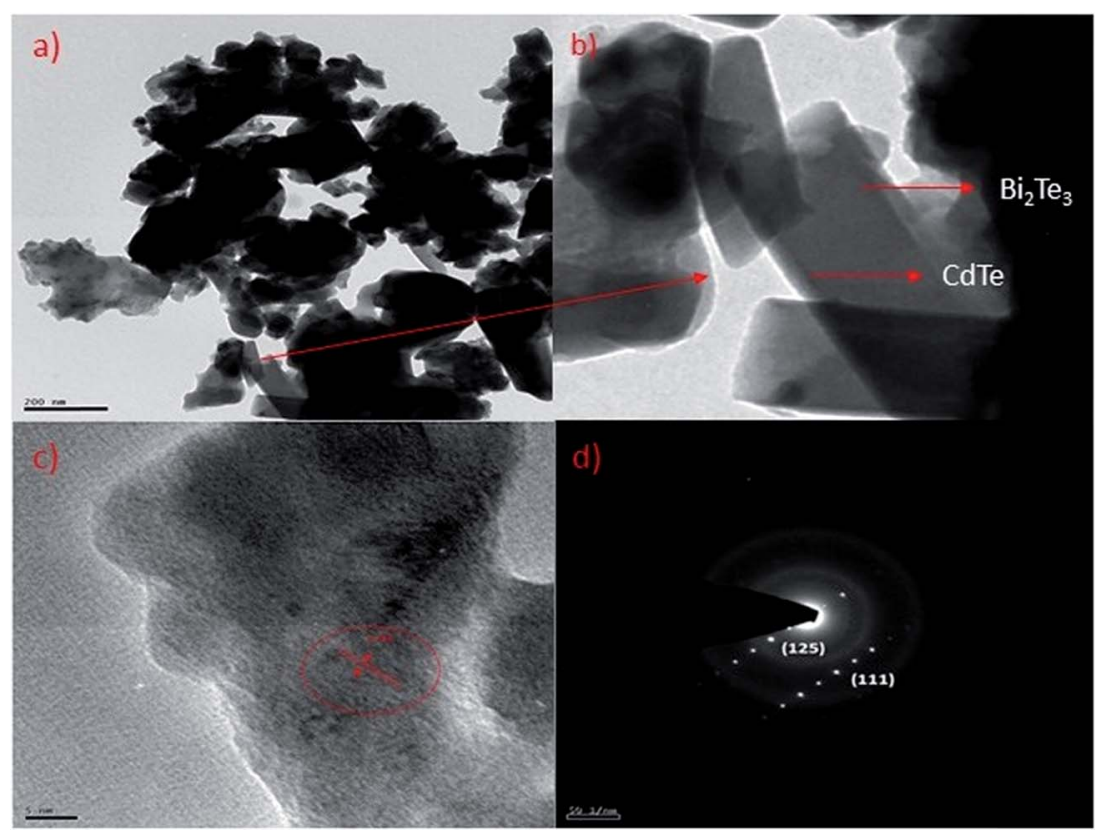

Fig. 3 (a) \& (b) Core/shell nanostructure of $\left(\mathrm{Bi}_{2} \mathrm{Te}_{3}\right)_{25}(\mathrm{CdTe})_{75}$; (c) \& (d) electron diffraction (SAED) shows the crystalline structure of $\mathrm{Bi}_{2} \mathrm{Te} \mathrm{e}_{3} / \mathrm{CdTe}$ in sample $\left(\mathrm{Bi}_{2} \mathrm{Te}_{3}\right)_{25}(\mathrm{CdTe})_{75}$.

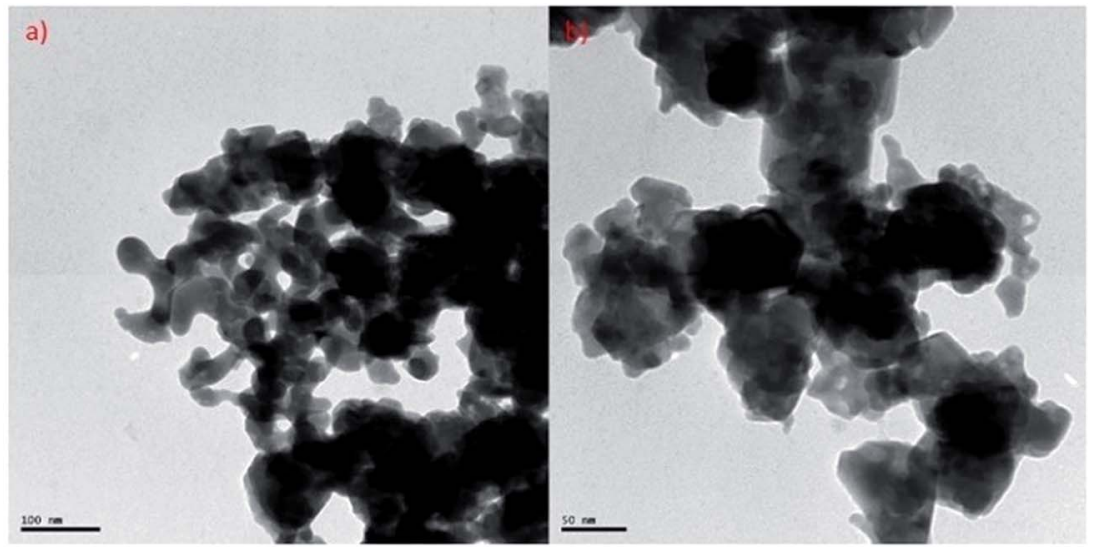

Fig. 4 TEM images of powder samples of (a) $\left(\mathrm{Bi}_{2} \mathrm{Te}_{3}\right)_{75}(\mathrm{CdTe})_{25}$ and (b) $\left(\mathrm{Bi}_{2} \mathrm{Te}_{3}\right)_{50}(\mathrm{CdTe})_{50}$. 


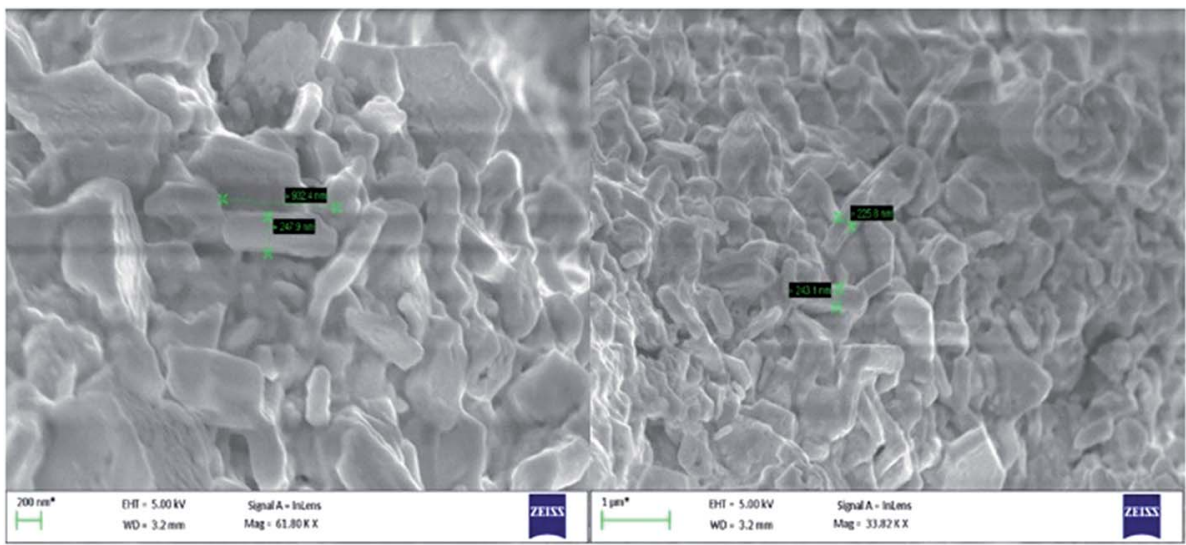

Fig. 5 FESEM morphology of the sample $\left(\mathrm{Bi}_{2} \mathrm{Te}_{3}\right)_{25}(\mathrm{CdTe})_{75}$ having nanorods approximately $240 \mathrm{~nm}$ in size.
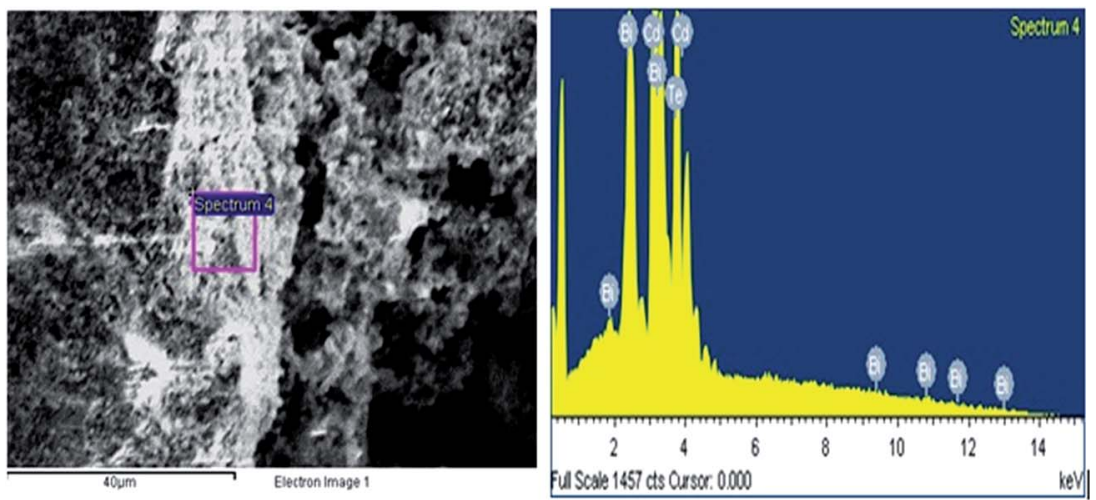

Fig. 6 EDX spectrum of $\left(\mathrm{Bi}_{2} \mathrm{Te}_{3}\right)_{25}(\mathrm{CdTe})_{75}$ sample.

outer morphology of the sample $\left(\mathrm{Bi}_{2} \mathrm{Te}_{3}\right)_{25}(\mathrm{CdTe})_{75}$ was observed by FESEM, which show that nanorods, approximately $240 \mathrm{~nm}$ in size, are present in the sample. The atomic ratio of Te to $\mathrm{Bi}$ to $\mathrm{Cd}$ obtained from the quantitative analysis of $\mathrm{Te}, \mathrm{Bi}$, and $\mathrm{Cd}$ in the EDX spectrum has an atomic weight percentage ratio of $40.90: 9.99: 49.11$ and a weight percentage ratio for Te, Bi and Cd as $40.69: 16.27: 43.04$, respectively, indicating that the ratio of $\left(\mathrm{Bi}_{2} \mathrm{Te}_{3}\right)_{25}(\mathrm{CdTe})_{75}$ is similar to the $25: 75$ ratio shown in Fig. 6 .

The transmittance and reflectance shows the structure of the nanorods. In Fig. 7(a), the transmittance image obtained using an advanced polarization microscope shows the structure of nanorods with a $400 \times$ magnification. Fig. 7 (b) presents the reflectance image, showing the dark-green colored core spots of $\mathrm{Bi}_{2} \mathrm{Te}_{3}$ inside the orange colored CdTe shell.

The energy band gap of the sample was obtained at different ratios. In $\left(\mathrm{Bi}_{2} \mathrm{Te}_{3}\right)_{50}(\mathrm{CdTe})_{50}$ sample, the bismuth telluride ratio is equal to that of CdTe. The energy band gap was $1.76 \mathrm{eV}$ due to doping, resulting in a higher band gap. In combination with $\left(\mathrm{Bi}_{2} \mathrm{Te}_{3}\right)_{75}(\mathrm{CdTe})_{25}$, the proportion of bismuth telluride was greater than that of CdTe, resulting in a lower band gap of $1.25 \mathrm{eV}$. This shows that the concentration of bismuth telluride affects the energy band gap of cadmium telluride, which leads to a decrease in the efficiency of solar cells; however, in $\left(\mathrm{Bi}_{2}{ }^{-}\right.$ $\left.\mathrm{Te}_{3}\right)_{25}(\mathrm{CdTe})_{75}$, the ratio of bismuth telluride, influencing the energy band gap of CdTe, was very low $(\approx 0.5 \%)$, such that the energy value of the sample was equal to the standard band gap of CdTe $(1.44 \mathrm{eV}) .{ }^{28-31}$ This shows that bismuth telluride with a ratio of $\left(\mathrm{Bi}_{2} \mathrm{Te}_{3}\right)_{25}(\mathrm{CdTe})_{75}$ does not affect the band gap of CdTe. $\mathrm{Bi}_{2} \mathrm{Te}_{3}$, which exhibits thermoelectric properties, only supports the increase in the solar cell efficiency and does not
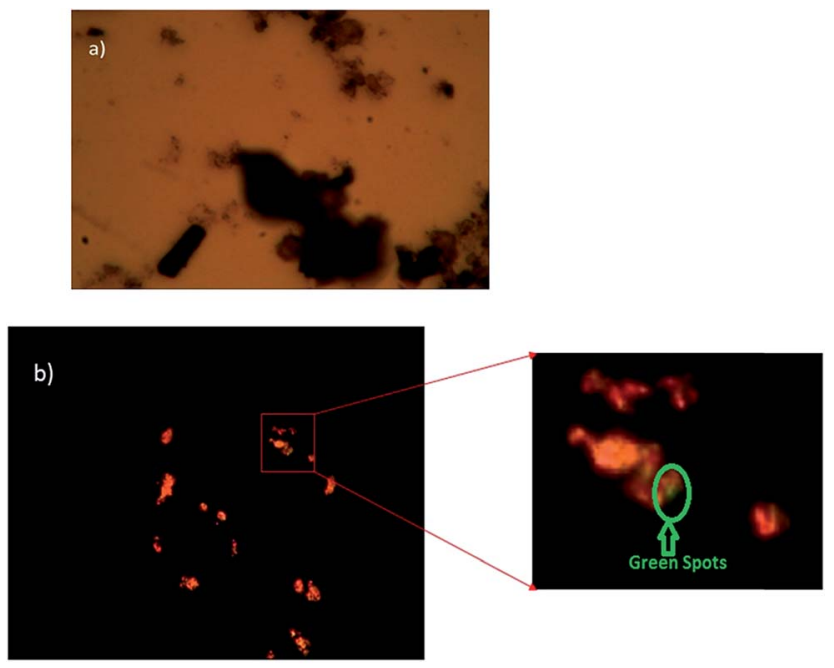

Fig. 7 (a) Transmittance image of $\mathrm{Bi}_{2} \mathrm{Te}_{3} / \mathrm{CdTe}$ nanorods and (b) the reflectance image of $\mathrm{Bi}_{2} \mathrm{Te}_{3} / \mathrm{CdTe}$ nanorods. 
a)

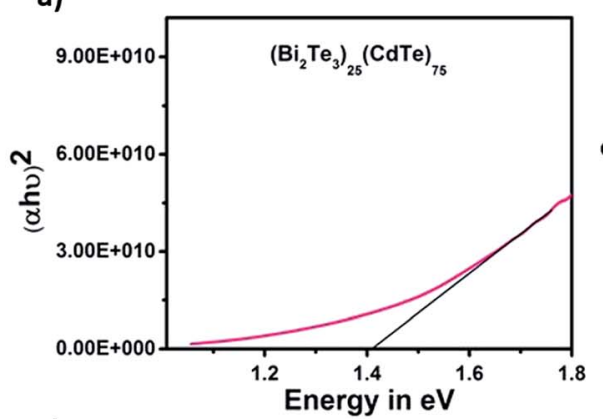

c)

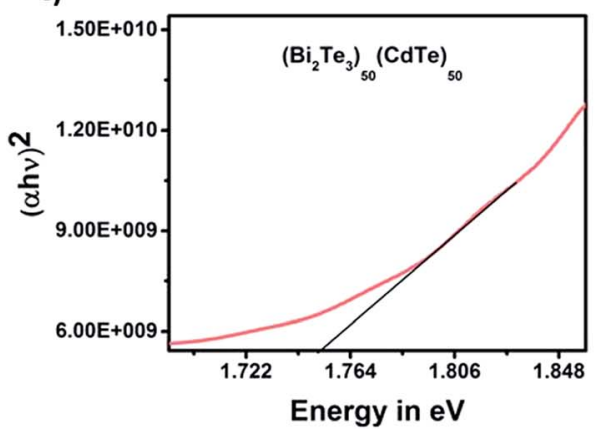

b)

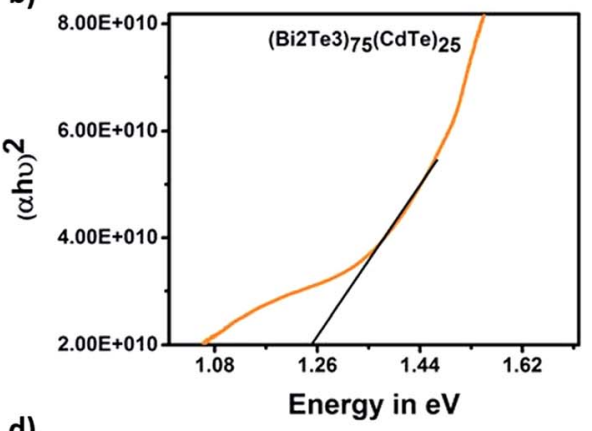

d)

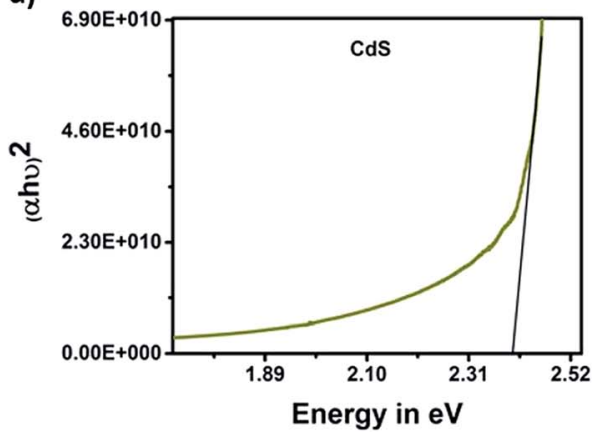

Fig. 8 The energy band gap graph of samples (a) $\left(\mathrm{Bi}_{2} \mathrm{Te}_{3}\right)_{25}(\mathrm{CdTe})_{75}$, fabricated device.

(b) $\left(\mathrm{Bi}_{2} \mathrm{Te}_{3}\right)_{75}(\mathrm{CdTe})_{25}$, (c) $\left(\mathrm{Bi}_{2} \mathrm{Te}_{3}\right)_{50}(\mathrm{CdTe})_{50}$, and (d) $\mathrm{CdS}$ layer in the

affect the band gap in the sample $\left(\mathrm{Bi}_{2} \mathrm{Te}_{3}\right)_{25}(\mathrm{CdTe})_{75}$. Moreover, $\left(\mathrm{Bi}_{2} \mathrm{Te}_{3}\right)_{25}(\mathrm{CdTe})_{75}$ has a band gap of $1.45 \mathrm{eV}$, as shown in Fig. 8. The band gap of CdS is $2.41 \mathrm{eV}$, which is similar to its standard band gap.

The effect of $\mathrm{Bi}_{2} \mathrm{Te}_{3}$ in the photoanode on the charge recombination kinetics was investigated by analyzing the $I-V$ characteristics under sunlight at room temperature. Fig. 9 shows the output current and voltage to determine the efficiency of the solar cell. The calculation was performed as follows:

$$
\frac{V_{\mathrm{oc}} \times I_{\mathrm{sc}}}{\text { surface area }}=\mathrm{watt} / \mathrm{cm}^{2}
$$

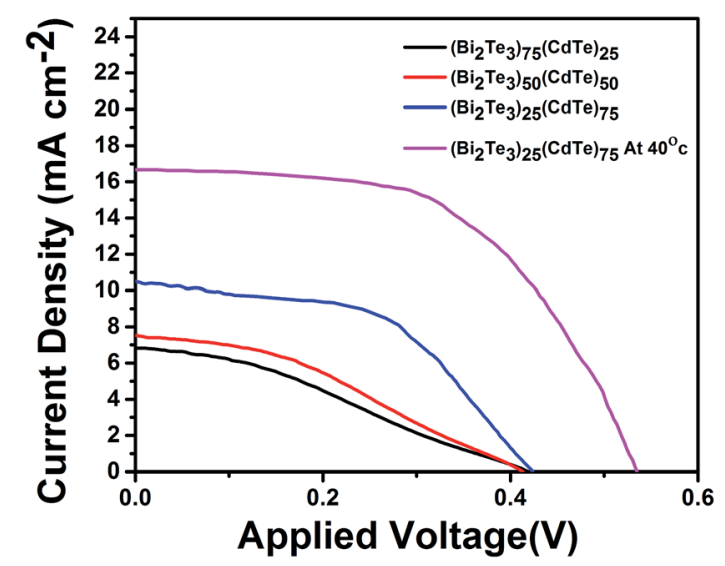

Fig. 9 Light irradiation (one sun) graph showing duration-dependent $I-V$ characteristics of the device.

$$
\frac{10000 \times \text { watt }}{\mathrm{cm}^{2}}=\text { watt } / \mathrm{m}^{2}
$$

The intensity of light was 700 watt per $\mathrm{m}^{2}$

$$
\eta(\%)=\left(\frac{\frac{\text { watt }}{\mathrm{m}^{2}}}{\text { light intensity }}\right) \times 100
$$

$\mathrm{Bi}_{2} \mathrm{Te}_{3}$, with a large thermoelectric figure of merit (ZT), is defined as $\sigma S^{2} T / k$, where $\sigma$ is the electrical conductivity, $S$ is the Seebeck coefficient or thermopower, $T$ is the absolute temperature, and $k$ is the thermal conductivity. $\mathrm{Bi}_{2} \mathrm{Te}_{3}$ has an enhanced ZT, a high Seebeck coefficient, an increased electrical conductivity, and a low thermal conductivity. The formation of acceptor and donor levels in the CdTe samples is associated with $\mathrm{Bi}$ concentration. The interdiffusion of Bi-doping with CdTe solar cells at lower concentration of Bi-doping makes $\mathrm{Bi}_{\mathrm{Cd}}{ }^{+}$to act as a donor. Therefore a higher $J_{\mathrm{sc}}$ in the sample $\left(\mathrm{Bi}_{2} \mathrm{Te}_{3}\right)_{25}(\mathrm{CdTe})_{75}$ was achieved as compared to that in the other concentration of $\mathrm{Bi}_{2} \mathrm{Te}_{3}$. This type of behavior is the mechanism of band bending at the GBs for CdTe solar cells with $\mathrm{Bi}_{2} \mathrm{Te}_{3} \cdot{ }^{32}$ Large amount of positively charged $\mathrm{Bi}_{\mathrm{Cd}}{ }^{+}$donor accumulated near the GBs makes the band bending to occur. The photogenerated electron-hole pairs due to charge separation near GBs cause band bending. Electrons are attracted towards the GBs core $\left(\mathrm{Bi}_{\mathrm{Cd}}{ }^{+}\right)$and flow through GBs, whereas the holes are transported through Cd to the back contact. A higher concentration of $\mathrm{Bi}_{2} \mathrm{Te}_{3}$ generates less power, thus lowering the efficiency. The efficiency was calculated for the combination of $\left(\mathrm{Bi}_{2} \mathrm{Te}_{3}\right)_{75}(\mathrm{CdTe})_{25}$ and $\left(\mathrm{Bi}_{2} \mathrm{Te}_{3}\right)_{50}(\mathrm{CdTe})_{50}$, 
Table 1 Summary of the photovoltaic properties of $\left(\mathrm{Bi}_{2} \mathrm{Te}_{3}\right)_{75}(\mathrm{CdTe})_{25}$, $\left(\mathrm{Bi}_{2} \mathrm{Te}_{3}\right)_{50}(\mathrm{CdTe})_{50},\left(\mathrm{Bi}_{2} \mathrm{Te}_{3}\right)_{25}(\mathrm{CdTe})_{75}$ and $\left(\mathrm{Bi}_{2} \mathrm{Te}_{3}\right)_{25}(\mathrm{CdTe})_{75}$ at $40{ }^{\circ} \mathrm{C}$

\begin{tabular}{lllll}
\hline Condition & $V_{\text {oc }}(\mathrm{mV})$ & $J_{\text {sc }}\left(\mathrm{mA} \mathrm{cm}^{-2}\right)$ & $\mathrm{FF}$ & $\eta(\%)$ \\
\hline$\left(\mathrm{Bi}_{2} \mathrm{Te}_{3}\right)_{75}(\mathrm{CdTe})_{25}$ & 419 & 7.273 & 29 & 0.89 \\
$\left(\mathrm{Bi}_{2} \mathrm{Te}_{3}\right)_{50}(\mathrm{CdTe})_{50}$ & 413 & 8.012 & 33 & 1.09 \\
$\left(\mathrm{Bi}_{2} \mathrm{Te}_{3}\right)_{25}(\mathrm{CdTe})_{75}$ & 423 & 10.34 & 51 & 2.27 \\
$\left(\mathrm{Bi}_{2} \mathrm{Te}_{3}\right)_{25}(\mathrm{CdTe})_{75}$ at $40^{\circ} \mathrm{C}$ & 535 & 16.66 & 54 & 4.85 \\
\hline
\end{tabular}

where the higher concentration of $\mathrm{Bi}_{2} \mathrm{Te}_{3}$ makes the device unusable as a solar cell. Fig. 9 shows that $\left(\mathrm{Bi}_{2} \mathrm{Te}_{3}\right)_{75}(\mathrm{CdTe})_{25}$ has $J_{\text {sc }}$ less when compared to the $J_{\text {sc }}$ of $\left(\mathrm{Bi}_{2} \mathrm{Te}_{3}\right)_{50}(\mathrm{CdTe})_{50}$, denoting that the concentration of $\mathrm{Bi}_{2} \mathrm{Te}_{3}$ affects the efficiency of the solar cell. Carrier (holes) concentration in $\left(\mathrm{Bi}_{2} \mathrm{Te}_{3}\right)_{75}(\mathrm{CdTe})_{25}$ and $\left(\mathrm{Bi}_{2} \mathrm{Te}_{3}\right)_{50}(\mathrm{CdTe})_{50}$ decreases with the increase in $\mathrm{Bi}_{2} \mathrm{Te}_{3}$ weight ratio resulting from the lower antistructure defects due to the large difference in the electronegativity between $\mathrm{Bi}$ and Te. This causes a decrease in the electrical resistivity and Seebeck coefficient. As the concentration of $\mathrm{Bi}_{2} \mathrm{Te}_{3}$ is higher, the cells lose capability as solar cells and power conversion gets reduced. This impact results in lower $J_{\mathrm{sc}}$ and $V_{\mathrm{oc}} \cdot\left(\mathrm{Bi}_{2} \mathrm{Te}_{3}\right)_{75}(\mathrm{CdTe})_{25}$ has $J_{\mathrm{sc}}$ of 7.273 and $V_{\text {oc }}$ of $0.41 \mathrm{mV}$ with a lower fill factor of 29 , which implies an efficiency of $0.89 \%$. $\left(\mathrm{Bi}_{2} \mathrm{Te}_{3}\right)_{25}(\mathrm{CdTe})_{75}$ is observed to have higher $J_{\mathrm{sc}}$ when compared to that for other concentrations. The band gap of CdTe is not affected by the concentration of $\mathrm{Bi}_{2} \mathrm{Te}_{3}$ in $\left(\mathrm{Bi}_{2} \mathrm{Te}_{3}\right)_{25}(\mathrm{CdTe})_{75}$, thus having higher $J_{\text {sc }}$ and $V_{\text {oc }}$ than the other two concentrations. Under conditions when the front side is illuminated, the power conversion efficiency of the solar cell with the FTO back contact was $2.27 \%$ with $V_{\text {oc }}=0.42 \mathrm{mV}, J_{\mathrm{sc}}$ $=10.34 \mathrm{~mA} \mathrm{~cm}^{-2}$, and $\mathrm{FF}=51.87 \%$ (Table 1 ).

The sample $\left(\mathrm{Bi}_{2} \mathrm{Te}_{3}\right)_{25}(\mathrm{CdTe})_{75}$ shows a better efficiency when kept at $40{ }^{\circ} \mathrm{C}$ on a hot plate, similar to the temperatures found in tropical regions. When the sample reaches $40{ }^{\circ} \mathrm{C}$, the $I-V$ characteristics of the sample $\left(\mathrm{Bi}_{2} \mathrm{Te}_{3}\right)_{25}(\mathrm{CdTe})_{75}$ show an increase in the power conversion efficiency. As the temperature increases in the fabricated solar cell, the overall power conversion efficiency increases approximately by $2.5 \%$ in the presence of $\mathrm{Bi}_{2} \mathrm{Te}_{3}$ in the sample $\left(\mathrm{Bi}_{2} \mathrm{Te}_{3}\right)_{25}(\mathrm{CdTe})_{75}$. This shows that bismuth telluride in combination with cadmium telluride exhibits its thermoelectric property. ${ }^{33}$ This response to temperature suggests that bismuth telluride will make a huge difference in the solar cell efficiency in the near future. At $40^{\circ} \mathrm{C}$, the overall power conversion efficiency was $4.8 \%$. The overall efficiency was increased by $24 \%$ when $\mathrm{Bi}_{2} \mathrm{Te}_{3}$ is in the composition ratio of $25 \%$ with $\mathrm{CdTe}^{34}$

\section{Conclusion}

$\mathrm{Bi}_{2} \mathrm{Te}_{3} / \mathrm{CdTe}$ nanorods were synthesized using a wet chemical method. XRD and TEM revealed the mean particle size of $\mathrm{Bi}_{2} \mathrm{Te}_{3} / \mathrm{CdTe}$ material; XRD showed that an improvement in the crystallinity of the sample results after heat treatment. TEM revealed the formation of rod-shaped nanoparticles. Polarization microscopy revealed the presence of $\mathrm{Bi}_{2} \mathrm{Te}_{3}$ and $\mathrm{CdTe}$ confirming that $\mathrm{Bi}_{2} \mathrm{Te}_{3}$ and CdTe are in the form of core shell nanorods. The efficiency of the sample $\left(\mathrm{Bi}_{2} \mathrm{Te}_{3}\right)_{25}(\mathrm{CdTe})_{75}$ increased by $24 \%$ with respect to increase in temperature. The present study shows that $\mathrm{Bi}_{2} \mathrm{Te}_{3} / \mathrm{CdTe}$ doping can enhance the efficiency of the thin film CdTe solar cells.

\section{Acknowledgements}

This work was supported by BK21PLUS, Creative Human Resource Development Program for IT Convergence. The authors would like to thank KBSI, Busan for SEM, TEM, XRD, and EDX analysis.

\section{References}

1 O. K. Varghese, M. Paulose and C. A. Grimes, Nat. Nanotechnol., 2009, 4, 592.

2 Encyclopedia of Nanoscience and Nanotechnology, ed. W. Chen, G. A. Joly, S. P. Wang and H. S. Nalwa, American Scientific Publishers, Los Angeles, CA, 2004, 4, pp. 689-718.

3 H. JyhGau, W.-R. Huang, C.-C. Wu, Y. Kang and C.-H. Ho, Solid State Phys., 2011, 170, 41.

4 N. R. Jana, L. Gearheart and C. Murphy, J. Phys. Chem. B, 2001, 105, 4065.

5 A. M. Alkilany, L. B. Thompson, S. P. Boulos, P. N. Sisco and C. J. Murphy, Adv. Drug Delivery Rev., 2012, 64, 190-199.

6 Y. Wang, L. Hosta-Rigau, H. Lomas and F. Caruso, Phys. Chem. Chem. Phys., 2011, 13, 4782.

7 D. Y. Wang, A. L. Rogach and F. Caruso, Nano Lett., 2002, 2, 857.

8 F. Caruso and C. Schuler, Langmuir, 2000, 16, 9595.

9 G. Decher, Science, 1997, 277, 1232.

10 G. Decher, Science, 1997, 277, 1232.

11 W. B. Stockton and M. F. Rubner, Macromolecules, 1997, 30, 2717.

12 S. Sukhishvili and S. Granick, J. Am. Chem. Soc., 2000, 122, 9550.

13 E. Guillen, E. Azaceta, L. Peter, A. Zukal, R. Tena-Zaera and J. Anta, Energy Environ. Sci., 2011, 4, 3400.

14 M. Law, L. E. Greene, J. C. Johnson, R. Saykally and P. D. Yang, Nat. Mater., 2005, 4, 455.

15 M. Quintana, T. Edvinsson, A. Hagfeldt and G. Boschloo, J. Phys. Chem. C, 2007, 111, 1035.

16 J. B. Baxter and E. S. Aydil, Appl. Phys. Lett., 2005, 86, 053114. 17 T. Coutts, X. Wu, P. Sheldon and D. Rose, 2nd IEEE World Photovoltaic Specialists Conference, Vienna, Austria, 1998.

18 D. H. Rose, F. S. Hasoon, R. G. Dhere, D. S. Albin, R. M. Ribelin, X. S. Li, Y. Mahathongdy, T. A. Gessert and P. Sheldon, Progress in Photovoltaics: Research and Applications, 1999, 7, 331-340.

19 J. Poortmans and V. Arkhipov, Thin Film Solar Cells Fabrication, Characterization and Applications, John Wiley \& Sons Ltd, 2006.

20 I. O. Oladeji, L. Chow, C. S. Ferekides, V. Viswanathan and Z. Zhao, Solar Energy Materials \& Solar Cells, 2000, vol. 61, pp. 203-211.

21 S. Gupta, S. Neeleshwar, V. Kumar and Y. Y. Chen, Adv. Mat. Lett., 2012, 3(1), 50-54. 
22 X. S. Li, D. Albin, S. Asher, H. Moutinho, B. Keyes, R. Matson, F. Hasoon and P. Sheldon, AIP Conf. Proc., 1995, 353, 376-383.

23 M. Melvin David Kumar and S. Devadason, Appl. Nanosci., 2013, 3, 453-459.

24 I. H. Wang, L. Sun, Y. Li, X. Fei, M. Sun, C. Zhang, Y. Li and Q. Yang, Langmuir, 2011, 27, 11609-11615.

25 H. Arizpe-Chavez, J. Phys. Chem. Solids, 2000, 61, 511-518.

26 I. H. Wang, L. Sun, Y. Li, X. Fei, M. Sun, C. Zhang, Y. Li and Q. Yang, Langmuir, 2011, 27, 11609-11615.

27 J. Yang, Y. Gao, J. W. Kim, Y. He, R. Song, C. W. Ahn and Z. tang, Phys. Chem. Chem. Phys., 2010, 1238, 11900-11904.

28 S. J. Fonash, Solar Cell Device Physics, Academic Press, New York, 1977.
29 A. L. Fahrenbruch and R. H. Bube, Fundamentals of Solar Cells, Academic Press, New York, 1983.

30 K. L. Chopra and S. R. Das, Thin Film Solar Cells, Plenum Press, New York, 1983.

31 A. Milnes and D. Feucht, Heterojunctions and Metalsemiconductor Junctions, Academic Press, New York, 1972.

32 R. Tang, Z. Wang, W. Li, L. Feng, J. Zhang, L. Wu, B. Li, G. Zeng and W. Wang, Sol. Energy Mater. Sol. Cells, 2014, 121, 92-98.

33 T. D. T. Ung, T. K. C. Tran, T. N. Pham, D. N. Nguyen, D. K. Dinh and Q. L. Nguyen, Adv. Nat. Sci.: Nanosci. Nanotechnol., 2012, 3, 043001.

34 T. Chen, G. Hong Guai, C. Gong, W. Hu, J. Zhu, H. Yang, Q. Yan and C. M. Li, Energy Environ. Sci., 2012, 5, 6294-6298. 